\title{
Contribution of oil palm isoprene emissions to tropospheric ozone levels in the Distrito Metropolitano de Quito (Ecuador)
}

\author{
R. Parra \\ Corporación para el Mejoramiento del Aire de Quito, Corpaire, \\ Quito, Ecuador
}

\begin{abstract}
Volatile organic compound (VOC) emissions from vegetation are important in the Distrito Metropolitano de Quito (DMQ). In particular, oil palm (Elaeis guineensis) isoprene emissions are significant near the DMQ. Oil palm cultivation is promoted because of the growing demand for biodiesel production. The contribution of isoprene from oil palm to tropospheric ozone $\left(\mathrm{O}_{3}\right)$ production was estimated by numerical simulation for the period 2-28 of September 2006, using estimates of emissions from the DMQ in the Eulerian chemical transport model WRF-Chem. On-road traffic, power facilities and other industries, vegetation, services stations and solvent use were considered as emission sources, under the following scenarios: 1) without oil palm, 2) with oil palm plantation in 2003; and, 3) with an expected future plantation. Two groups of emission rates were used: 1) a group of mid-range emission factors (up to 51 $\left.\mu \mathrm{g} \mathrm{g}^{-1} \mathrm{~h}^{-1}\right)$ and 2) a high isoprene emission factor $\left(172.9 \mu \mathrm{g} \mathrm{g}^{-1} \mathrm{~h}^{-1}\right)$. Results indicate that increasing areas of oil palm plantations in the future could increase $\mathrm{O}_{3}$ concentrations. Scenario 3) with the high emission factor, provides maximum hourly anomalies of $17.9 \mu \mathrm{g} \mathrm{m}^{-3}$ over the urban zone. Scenario 3), with the midrange emission factors, results in maximum hourly anomalies of $2.7 \mu \mathrm{g} \mathrm{m}^{-3}$.

Keywords: Elaeis guineensis, WRF-Chem, numerical simulation, volatile organics compounds.
\end{abstract}

\section{Introduction}

Volatile organic compound (VOC) emissions from vegetation are important in the Distrito Metropolitano de Quito $(\boldsymbol{D M Q})$. Isoprene $\left(\mathrm{C}_{5} \mathrm{H}_{8}\right)$ is a reactive VOC 
whose emissions are indirectly related to photosynthesis. $\mathrm{C}_{5} \mathrm{H}_{8}$ is synthesized and emitted by different plant species when exposed to Photosynthetically Active Radiation (PAR). $\mathrm{C}_{5} \mathrm{H}_{8}$ emissions increase with temperature up to a maximum, and decrease again at higher temperatures (Guenther et al. [1]).

CORPAIRE [2] estimated that about $43 \%\left(21.7 \mathrm{kt} \mathrm{a}^{-1}\right)$ of total VOC emissions in the domain of the DMQ are produced by vegetation. About $57 \%$ of them $(12.4$ $\mathrm{kt} \mathrm{a}^{-1}$ ) are $\mathrm{C}_{5} \mathrm{H}_{8}$. About $56 \%$ of $\mathrm{C}_{5} \mathrm{H}_{8}$ is produced by oil palm (Elaeis guineensis) plantations. This species has been widely planted in Ecuador. According to statistics from the Ministerio de Agricultura [3], in 2005 oil palm coverage in Ecuador was about 207000 ha. Oil palm was introduced near the Equator, replacing large stretches of native forest. Further expansion of oil palm plantations can be expected, owing to its high performance and low production costs in the region, and the growing demand for its oil for biodiesel production.

Ozone $\left(\mathrm{O}_{3}\right)$ can be produced when reactive VOCs mix with nitrogen oxides under incoming solar radiation. Typically $\mathrm{O}_{3}$ concentrations are higher during midday and early afternoon hours, when both temperature and solar radiation are higher. Because of the magnitude of $\mathrm{C}_{5} \mathrm{H}_{8}$ emissions by oil palm and the expected increase of oil palm plantations, the contribution of oil palm isoprene emissions to tropospheric $\mathrm{O}_{3}$ formation in the DMQ region was estimated.

\section{Method}

The numerical simulation of air quality was performed for the period 2-28 September 2006, using emissions provided by the Sistema de Gestión del Inventario de Emisiones del DMQ (SIGIEQ) (Mina and Parra [4]). At present, emissions from on-road traffic, power facilities and other industries, vegetation, service stations and by use of solvents are included within the SIGIEQ. Hourly gas-phase emissions were speciated according to the Regional Acid Deposition Model (RADM) chemical mechanism (Stockwell et al. [5]). They were used with the Weather Research and Forecasting with Chemistry (WRF-Chem) [6] model, to simulate air quality in the region of Quito.

Fig. 1 depicts the location of Quito, the master and the two nested domains used for simulation. The first two $(\mathrm{d} 01: 27 \times 27 \mathrm{~km}, \mathrm{~d} 02: 9 \times 9 \mathrm{~km})$ are used only for meteorological simulations. For the second subdomain $(\mathrm{d} 03$ : $3 \times 3 \mathrm{~km})$, the chemical transport option is also activated.

The DMQ is located near the Equator. It has a complex topography. Subdomain d03 has zones with height lower than 800 masl and higher than 4000. Quito has an average altitude of 2800 masl. The Guagua Pichincha volcano is allocated west of Quito (Fig. 2.) Subdomain d03 is a squared region (about $110 \mathrm{~km} \mathrm{x} 110 \mathrm{~km}$ ) with Quito allocated at its center. Fig. 2 also depicts the oil palm coverage in 2003, obtained from the SIGAGRO system, (Ministerio de Agricultura y Ganadería del Ecuador [7]). It covered about $8.7 \%$ of the Subdomain $\mathrm{d} 03$.

\subsection{VOC emissions by vegetation}

Isoprene, monoterpenes and other VOC emissions were estimated using the algorithm by Guenther et al. [8], considering temperature and solar radiation as 

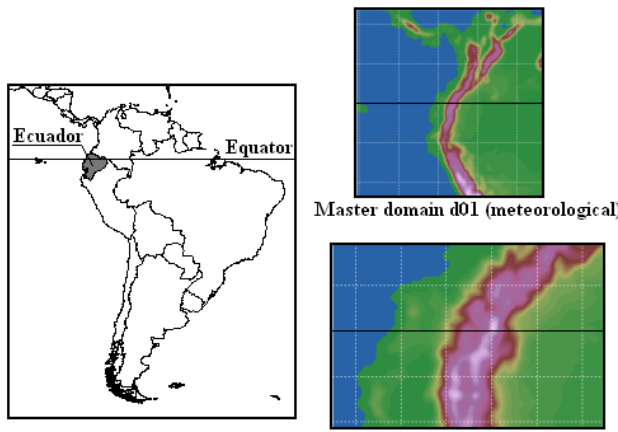

Subdomain d01 (meteorological)

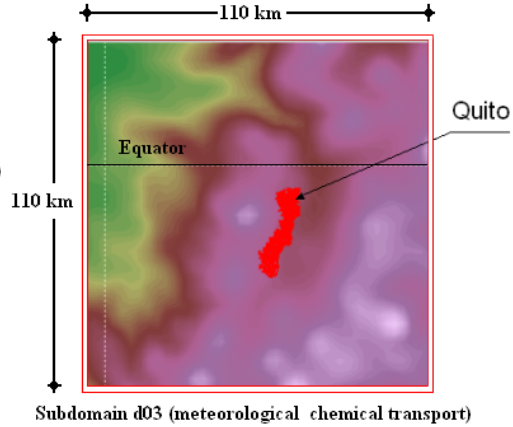

Figure 1: $\quad$ Location of Ecuador and domains for modeling. Subdomain d03 is a squared region (about $110 \mathrm{~km}$ by side) with Quito allocated at its center.
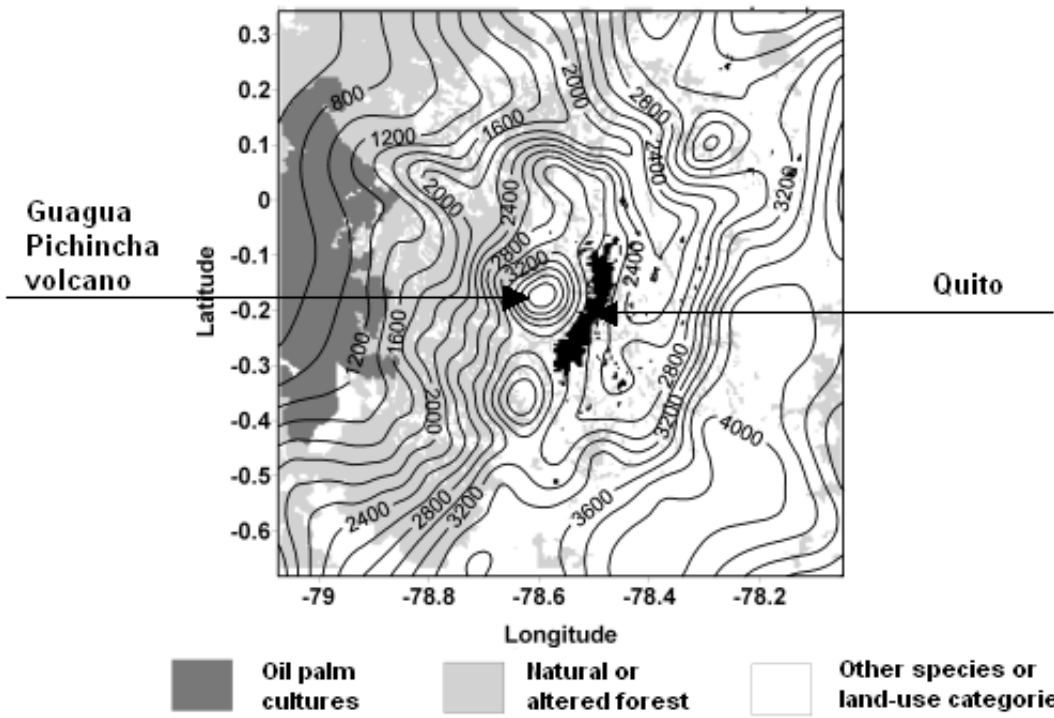

Oil palm

Ilatural or cultures

altered forest

Other species or land-use categories

Figure 2: Location of Quito, topography (masl) and oil palm coverage in 2003.

physical drivers of emission factors. Hourly maps of these drivers were provided by the WRF-Chem model.

\subsection{Isoprene emission factors for oil palm}

Two groups of isoprene emission factors (EFs) were used:

1) A group of mid-range EFs, up to $55 \mu \mathrm{g} \mathrm{g}^{-1} \mathrm{~h}^{-1}$ (at standard conditions, 30 ${ }^{\circ} \mathrm{C}$ of temperature and $1000 \mu \mathrm{mol} \mathrm{m} \mathrm{s}^{-1}$ of PAR), provided by Dr. Sue Owen 
(CEH, Edinburgh, UK; personal communication). Fig. 3 depicts these EFs, which vary during daytime. Wilkinson et al. [9] found that they are under strong circadian control.

2) A high EF: $172.9 \mu \mathrm{g} \mathrm{g}^{-1} \mathrm{~h}^{-1}$ from Kesselmier and Staudt [10].

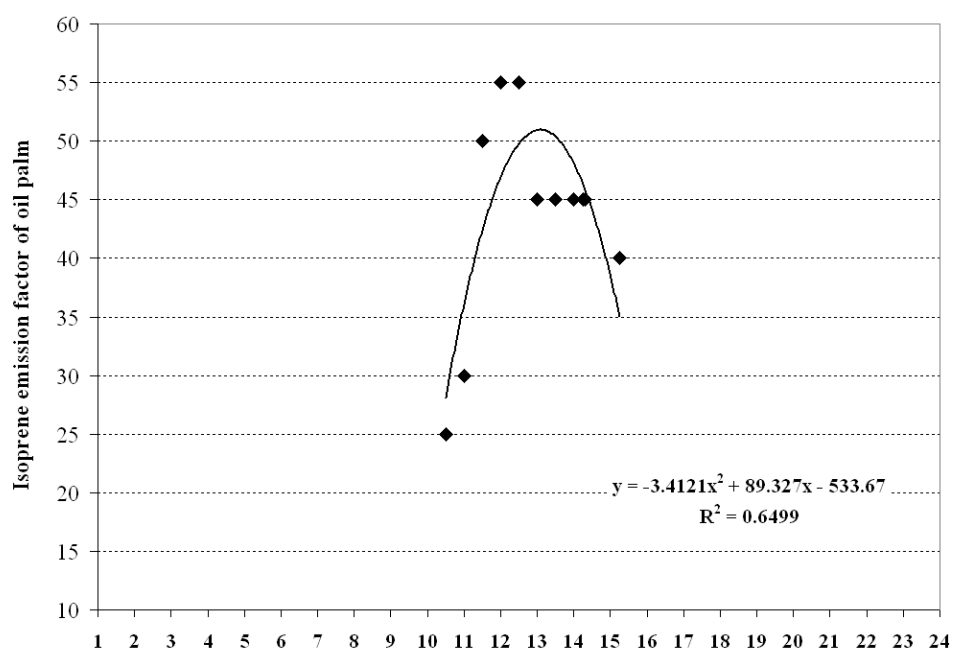

Figure 3: Isoprene emission factors $\left(\mu \mathrm{g} \mathrm{g}^{-1} \mathrm{~h}^{-1}\right)$ of oil palm (Owen et al., in preparation).

\section{Scenarios}

Five scenarios were considered:

1) Without oil palm (WOP), replacing the 2003 oil palm coverage with natural forest

2) With oil palm according to the coverage of Fig. 2 (8.7\% of the Subdomain d03) and the group of mid-range EFs (OP1)

3) With oil palm according to the coverage of Fig. 2 (8.7\% of the Subdomain d03) and the high EF (OP2)

4) Projection of more oil palm (to $15.6 \%$ of the Subdomain d03) and the group of mid-range EFs (MOP1)

5) Projection of more oil palm (to $15.6 \%$ of the Subdomain d03) and the high EF (MOP2)

Fig. 4 shows the oil palm plantation for these scenarios. Oil palm in 2003 reached zones with average temperatures of 18 and $19^{\circ} \mathrm{C}$. Projected coverage for MOP1 and MOP2 scenarios was defined assuming that the increase of oil palm plantations will be produced over zones with average temperature equal or higher than of $19^{\circ} \mathrm{C}$, at the left upper zone of the Subdomain $\mathrm{d} 03$. 


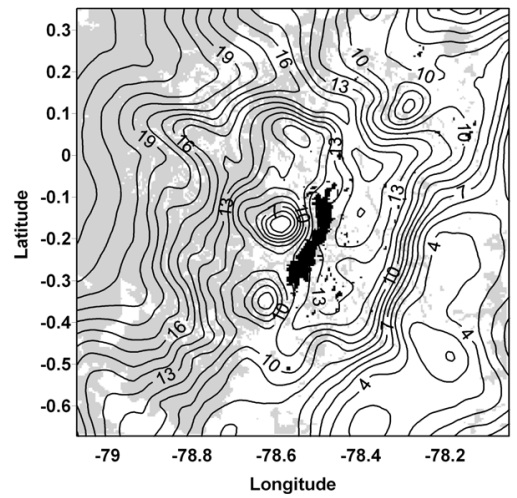

(a) Land-use map for WOP scenario.

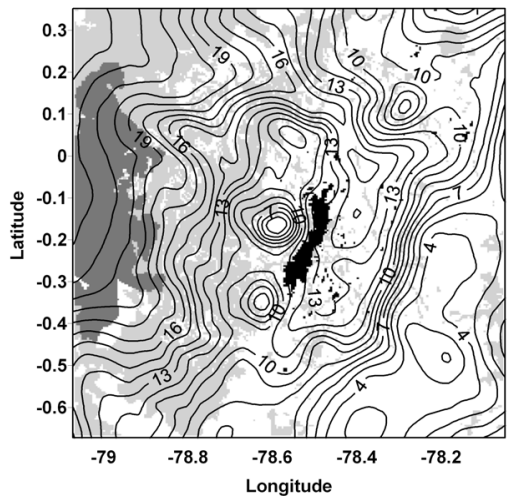

(b) Land-use map for OP1 and OP2.

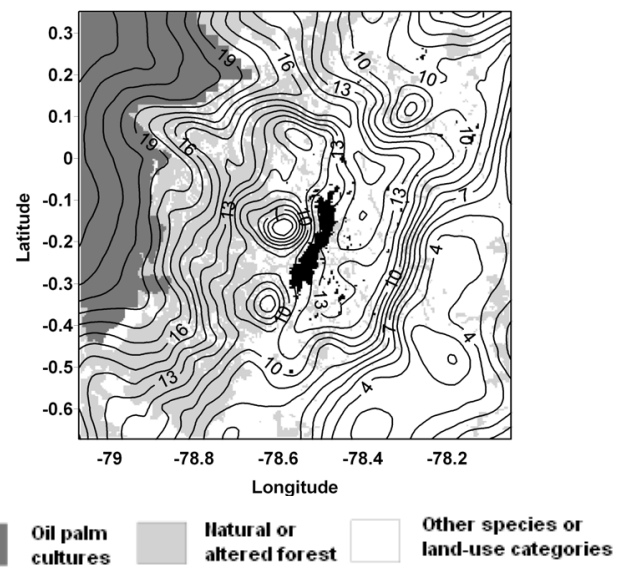

c) Land-use map for MOP1 and MOP2.

Figure 4: (a) Land-use map for the WOP scenario and average temperature curves $\left({ }^{\circ} \mathrm{C}\right)$, (b) Land-use map for the year 2003 used for the OP1 and OP2 scenarios (oil palm coverage: $8.7 \%$ of the Subdomain d03), (c) Land-use map for the MOP1 and MOP2 scenarios (oil palm coverage: $15.6 \%$ of the Subdomain d03).

\section{Results}

Fig. 5 depicts the hourly $\mathrm{O}_{3}$ anomalies between the MOP1, MOP2 and WOP scenarios, during 14:00 to 16:00 of 24-Sep-2006. They were the highest values found during the period of study. Over the urban region of Quito, anomalies reached $17.9 \mu \mathrm{g} \mathrm{m}^{-3}$ for the MOP2 scenario, and $2.7 \mu \mathrm{g} \mathrm{m}^{-3}$ for the MOP1 scenario. 


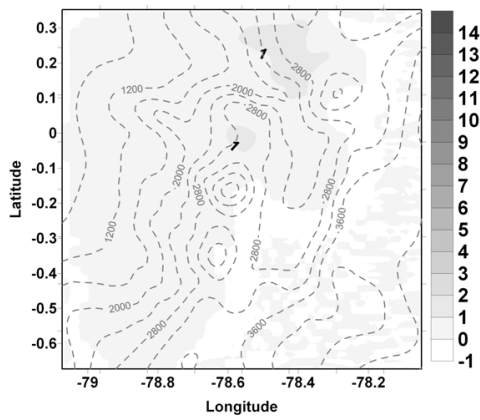

(a) MOP1 - WOP. 14:00. 24-Sep2006

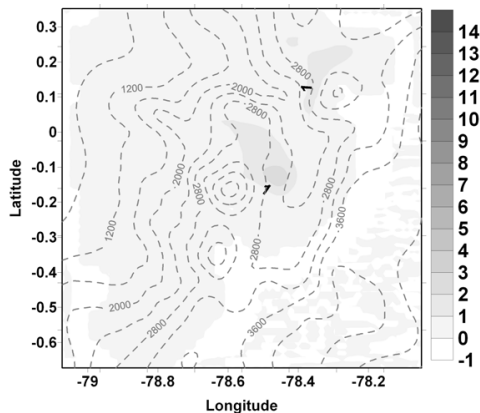

(c) MOP1 - WOP 15:00. 24-Sep2006

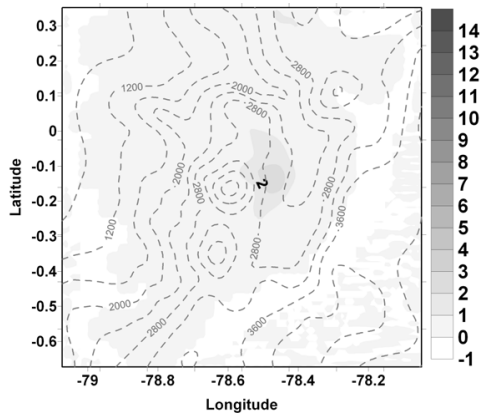

(e) MOP1 - WOP 16:00. 24-Sep2006

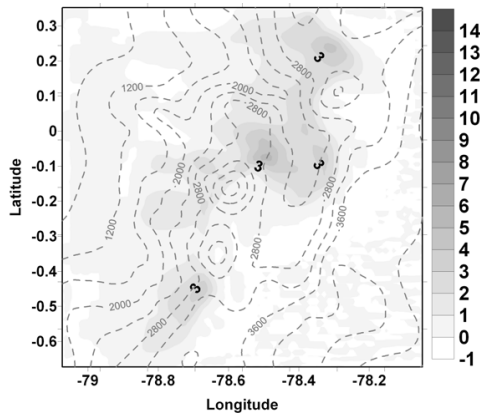

(b) MOP2 - WOP. 14:00. 24-Sep2006

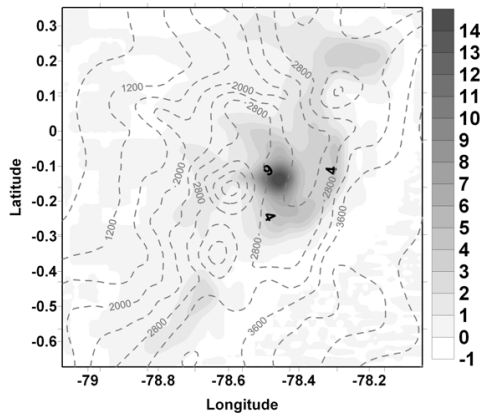

(d) MOP2 - WOP 15:00. 24-Sep2006

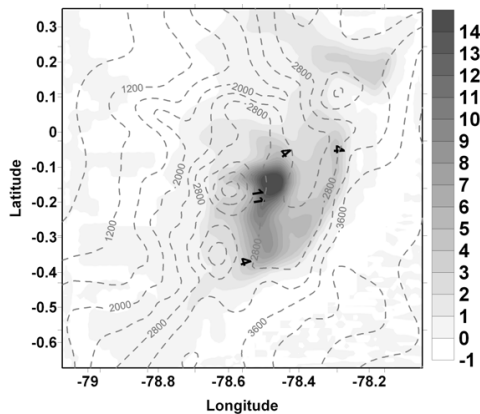

(f) MOP2 - WOP 16:00. 24-Sep-2006

Figure 5: Hourly $\mathrm{O}_{3}$ anomalies $\left(\mu \mathrm{g} \mathrm{m}^{-3}\right)$ during 24 September 2006: (a) MOP1-WOP, 14:00, (b) MOP2-WOP, 14:00, (c) MOP1-WOP, 15:00, (d) MOP2-WOP, 15:00, (e) MOP2-WOP, 16:00, (f) MOP2WOP, 16:00. They were the highest anomalies found during the period of study. Over Quito, anomalies reached $17.9 \mu \mathrm{g} \mathrm{m}^{-3}$ for the MOP2 scenario, and $2.7 \mu \mathrm{g} \mathrm{m}^{-3}$ for the MOP1 scenario. 
For the period of study and over the urban region, the highest anomalies ranged from 5.5 to $17.9 \mu \mathrm{g} \mathrm{m}^{-3}$ for the MOP2 scenario, and from 1 to $2.7 \mu \mathrm{g} \mathrm{m}^{-3}$ for the MOP1 scenario. The highest anomalies ranged from 2.3 to $8.4 \mu \mathrm{g} \mathrm{m}^{-3}$ for the OP2 scenario; and from 0.4 to $1.4 \mu \mathrm{g} \mathrm{m}^{-3}$ for the OP1 scenario.

A network of 9 automatic air quality stations have been operating since July 2003 in the Quito region (Fig. 6). Data from Jipijapa (north of Quito; Fig. 6) were used to evaluate the model output.

Fig. 7 shows the hourly $\mathrm{O}_{3}$ concentrations $\left(\mu \mathrm{g} \mathrm{m}^{-3}\right)$, surface temperature $\left({ }^{\circ} \mathrm{C}\right)$, and global solar radiation ( $\mathrm{W} \mathrm{m}^{-2}$ ) during 23 to 28-Sep-2006, for the Jipijapa station (north of Quito, Fig. 6). Fig. 7 (a) shows clearly the highest increased $\mathrm{O}_{3}$ concentrations during the afternoon of 24-Sep-2006. Other days the anomalies are lower.

Fig. 8 depicts the 8 -hour $\mathrm{O}_{3}$ average anomalies between the MOP1, MOP2 and WOP scenarios, during 11:00 to 18:00 of 24-Sep-2006. Ozone anomalies reached until $6.5 \mu \mathrm{g} \mathrm{m}^{-3}$ for the MOP2 scenario, and $1 \mu \mathrm{g} \mathrm{m}^{-3}$ for the MOP1 scenario.

During the period of study, hourly $\mathrm{O}_{3}$ anomalies were higher at $15 \mathrm{~h} 00$ and 16h00 for the OP1 and OP2 scenarios, but at 17:00 for the MOP1 and MOP2 scenarios.

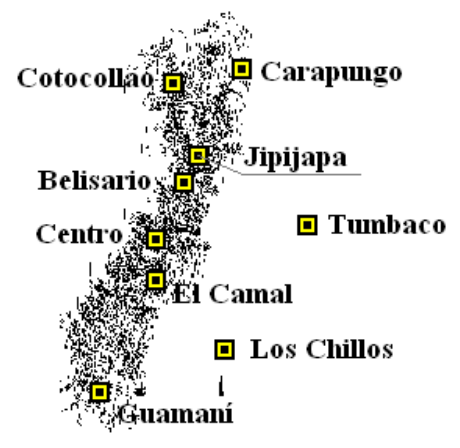

Figure 6: Zoom in of Quito and allocation of the automatic air quality stations.

\section{Conclusions}

Oil palm plantations could increase the tropospheric $\mathrm{O}_{3}$ in Quito. Potential range for maximum increase of hourly $\mathrm{O}_{3}$ concentrations $\left(2.7\right.$ to $\left.17.9 \mu \mathrm{g} \mathrm{m}^{-3}\right)$ was established under a projected growth of oil palm plantation (to $15.6 \%$ of the Subdomain d03). Increased values of hourly $\mathrm{O}_{3}$ concentrations for the 2003 coverage ranged from 1.4 to $8.4 \mu \mathrm{g} \mathrm{m}^{-3}$ )

To reduce uncertainty, it is necessary to measure the isoprene emission factors over the region of study. The modeling domain should be resized, because there are more oil palm plantations to the west of the actual domain used for air quality modeling. 


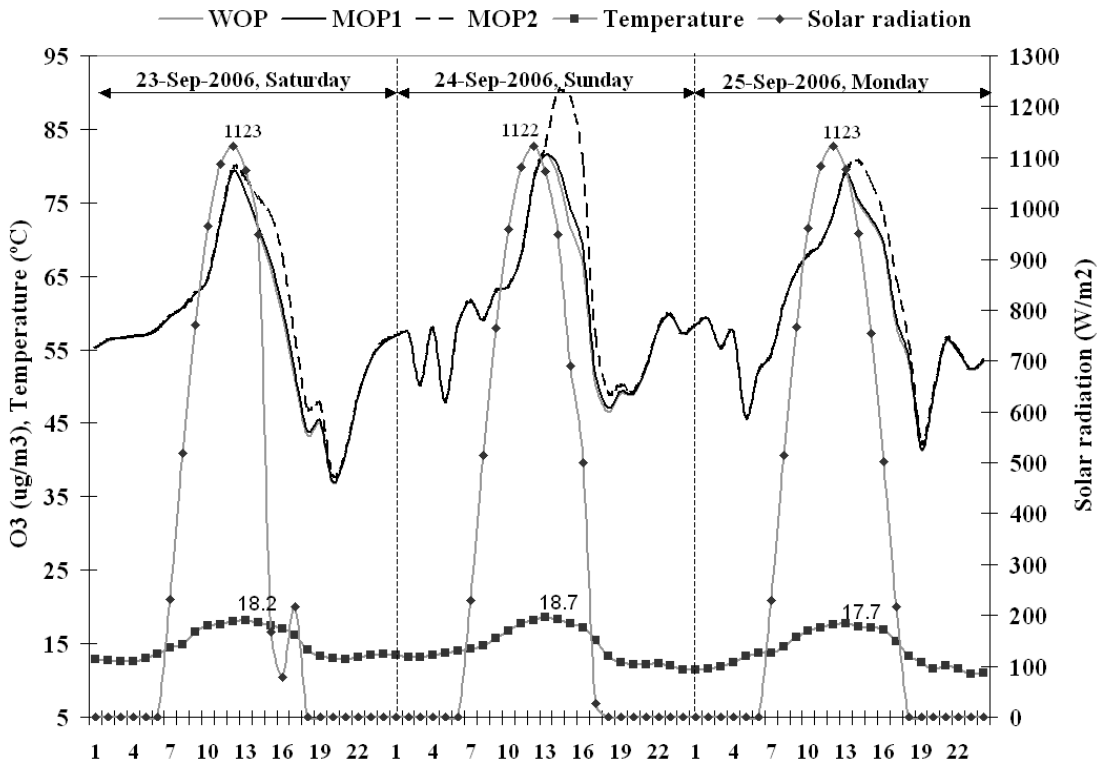

(a)

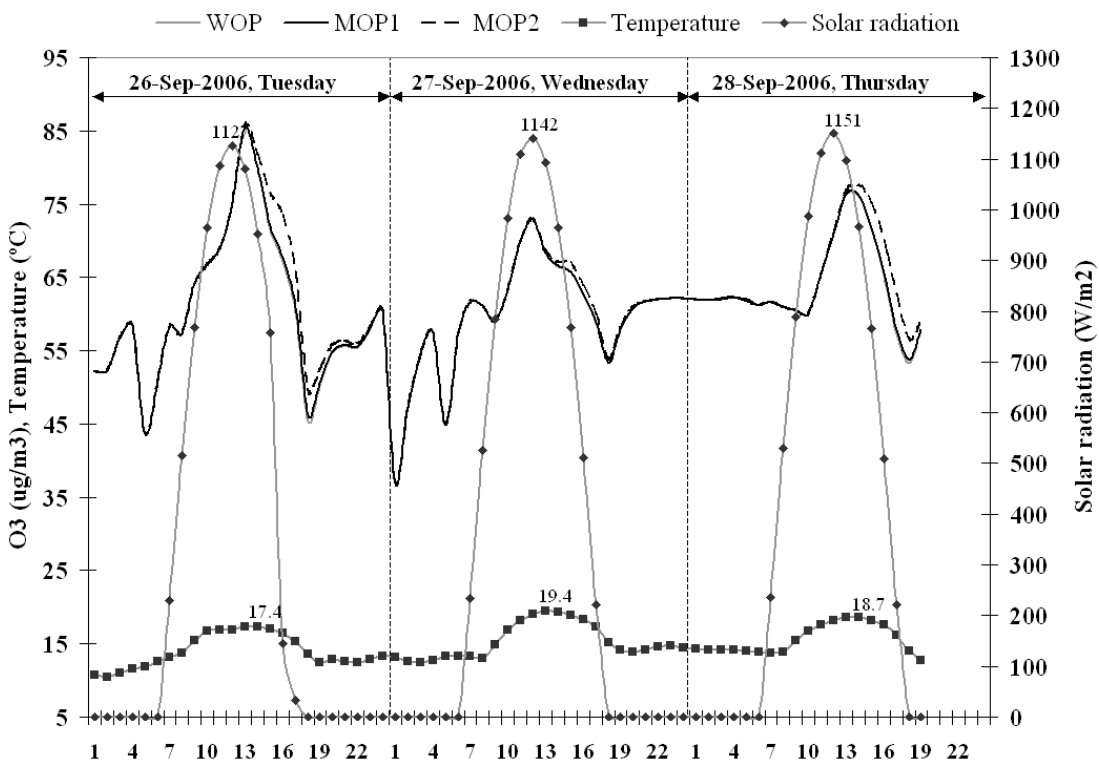

(b)

Figure 7: $\quad$ Hourly $\mathrm{O}_{3}$ concentrations $\left(\mu \mathrm{g} \mathrm{m}{ }^{-3}\right)$, surface temperature $\left({ }^{\circ} \mathrm{C}\right)$, and solar radiation $\left(\mathrm{W} \mathrm{m}^{-2}\right)$ for the Jipijapa station: (a) 23 to 25 , (b) 26 to 28 September 2006 . 


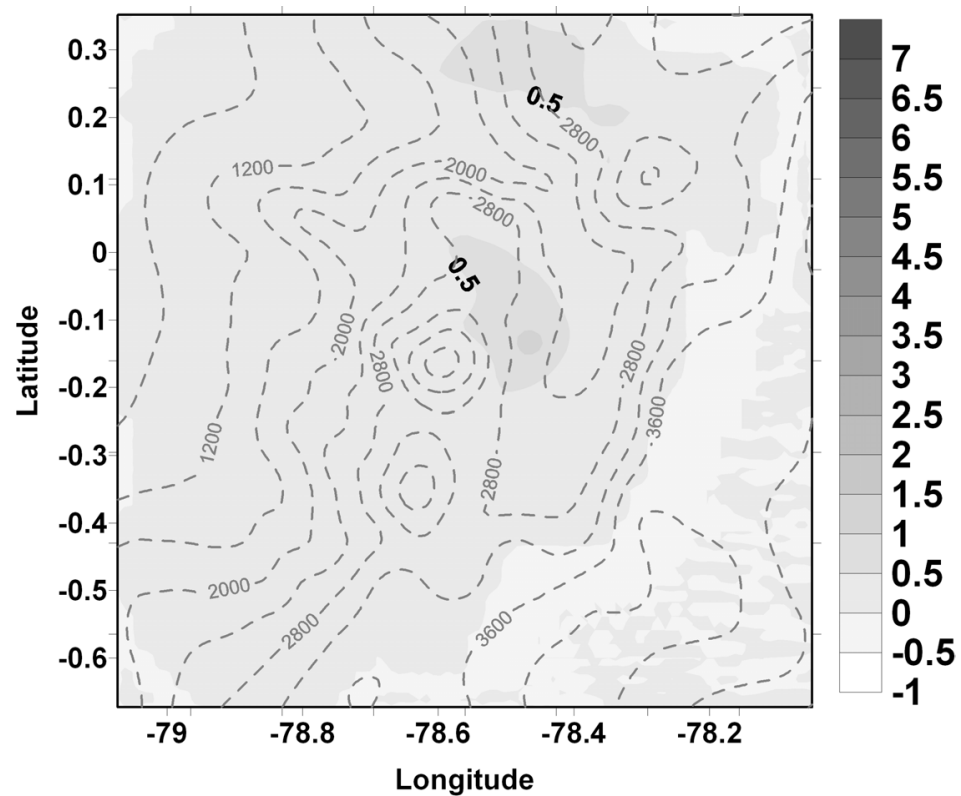

(a) MOP1-WOP. 24-Sep-2006

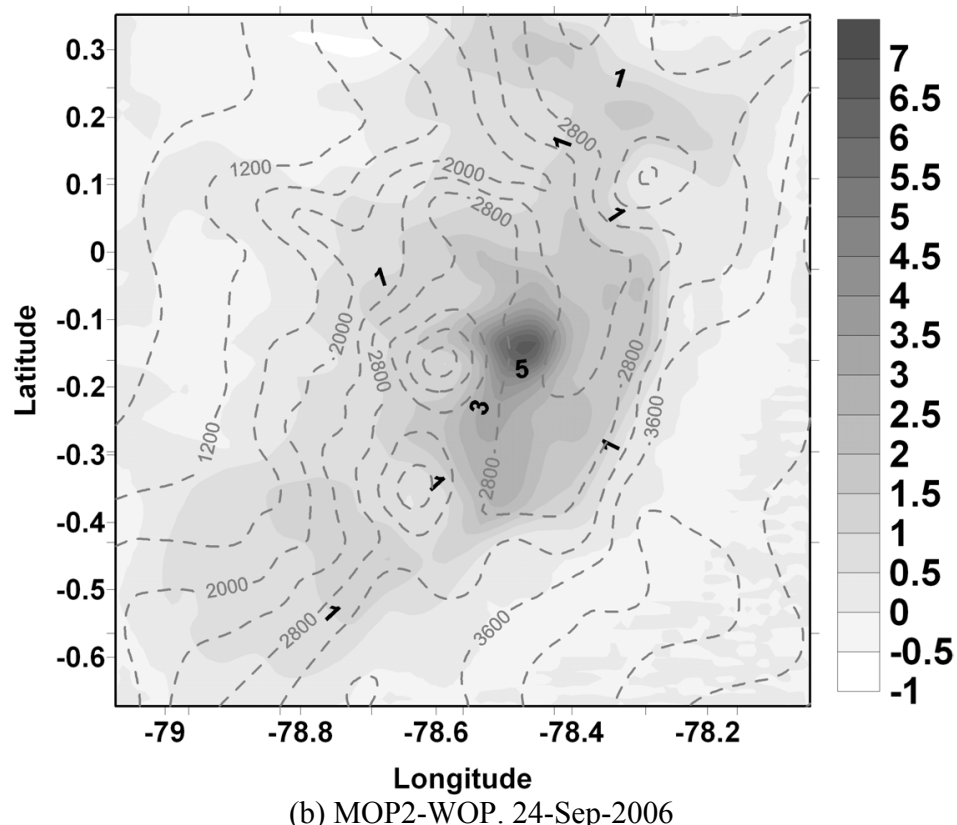

Figure 8: $\quad$-hour $\mathrm{O}_{3}$ average anomalies $\left(\mu \mathrm{g} \mathrm{m}^{-3}\right)$ during 24 September 2006: (a) MOP1-WOP, (b) MOP2-WOP. Anomalies reached $6.5 \mu \mathrm{g} \mathrm{m}^{-3}$ for the MOP2 scenario, and $1 \mu \mathrm{g} \mathrm{m}^{-3}$ for the MOP1 scenario. 


\section{Acknowledgement}

To Dr. Sue Owen who provided her unpublished isoprene emission factors for oil palm. She also checked this paper.

\section{References}

[1] Guenther, A.; Hewitt, C.N.; Erickson, D.; Fall, R.; Geron, C.; Graedel, T.; Harley, P.; Klinger, L.; Lerdau, M.; McKay, W.A.; Pierce, T.; Scholes, B., Steinbrecher, R.; Tallamraju, R.; Taylor, J. \& Zimmerman, P., A global model of natural volatile organic compound emissions. Journal of Geophysical Research, 100 (D5), pp. 8873 - 8892, 1995.

[2] CORPAIRE. Inventario de Emisiones del Distrito Metropolitano de Quito 2003. Quito-Ecuador, 2006.

[3] Ministerio de Agricultura, Ganadería, Acuacultura y Pesca del Ecuador, http://www.sica.gov.ec

[4] Mina, T. \& Parra, R. Sistema de Gestión del Inventario de Emisiones del Distrito Metropolitano de Quito (SIGIEQ), CORPAIRE, 1er Congreso Ecuatoriano Sobre la Gestión de la Calidad del Aire. Quito- Ecuador, 2006

[5] Stockwell, W., Middleton, P., Chang, J. \& Tang, X., The Second Generation Regional Acid Deposition Model Chemical Mechanism for Regional Air Quality Modeling. Journal of Geophysical Research, 95 (D10), pp. 16343 - 16367, 1990.

[6] Weather Research and Forecasting Model, http://wrf-model.org

[7] Ministerio de Agricultura y Ganadería, http://www.mag.gov.ec/sigagro/

[8] Guenther A.B., Zimmerman P.R. \& Harley P.C. Isoprene and Monoterpenes Emission Rate Variability: Model Evaluations and Sensitivity Analysis. Journal of Geophysical Research, 98(D7), pp. 12609 - 12617, 1993.

[9] Wilkinson, J.; Owen, S.; Possell, M.; Harwell, J.; Gould, P.; Hall, A.; Vickers, C. \& Hewitt, N. Circadian control of isoprene emissions from oil palm (Elaeis guineensis). The Plant Journal, 47, pp. 960 - 968, 2006.

[10] Kesselmeier J. \& Staudt M. Biogenic volatile organic compounds (voc): an overview on emission, physiology and ecology. Journal of Atmospheric Chemistry, 33, pp. $23-88,1999$. 